\title{
Price and Income Elasticities of Disaggregated Import Demand in Sri Lanka
}

\author{
T. M. Udayanthi Tennakoon* \\ Senior Assistant Director \\ Payments and Settlements Department \\ Central Bank of Sri Lanka
}

\begin{abstract}
The purpose of this study is to investigate Sri Lanka's disaggregated import demand functions and their price and income elasticities, for the post-liberalization period of 1977-2007. Although there exist many studies examining aggregate import demand, there appears to be a dearth of studies on estimating price and income elasticities import demand functions of Sri Lanka at a disaggregated level. This study aims at filling this gap by estimating disaggregated price and income elasticities for three major categories of imports, viz. consumer goods, intermediate goods and investment goods. To this end, the paper employs standard characterizations of import demand functions extensively discussed in the literature. The econometric estimates reveal that relative price is inelastic for all categories of consumer goods, intermediate goods and investment goods, implying that consumers may be less price sensitive. Further, the paper also examines the effects of changes in national income and foreign exchange availability on the demand for imported goods in Sri Lanka during 1977-2007. Based on these results several policy implications could be derived with regard to dependence on foreign trade, international finance, foreign reserve management and exchange rates, public finance, particularly taxation, as well as the impact of import demand in the face of external shocks on domestic prices and inflation.
\end{abstract}

* The author wishes to thank Dr. C. Amarasekara, Dr .P. K. G. Harischandra, Mr. C. A. Abeysinghe and Mr. V. S. B. W. Tennekoon for their valuable comments and suggestions. 


\section{Introduction}

Foreign trade is one of the major determinants of a country's foreign exchange flow. While exports bring foreign exchange to the country, imports help in increasing the utility of consumers through raising the level and variety of goods and services consumed. At the same time, the government can source revenue through taxes on exports and imports. However, trade volume and hence the associated potential revenue generation from trade-based taxes depends on the price and income elasticities of exports and imports. Therefore, to formulate or implement a policy related to foreign trade, it is very important to have a clear picture on the export and import demand determinants and their elasticity. Correct identification of the determinants and their impact on export and import demand would be a great assistance to reap the expected results of an imposed trade policy.

Elasticity of import demand is useful to make policy decisions on optimal trade taxes, currency devaluation to improve the balance of trade, estimation of the government revenue from trade related taxes and estimation of the fiscal implications of trade liberalisation. Given its importance, the economics literature contains substantial research in the area. Studies range from cross-sectional work across countries to time-series research of individual countries on export and import demand functions. A number of studies have focused on estimating the aggregate import demand in several countries, while some researchers have estimated disaggregated ${ }^{1 /}$ import demand functions. Identifying the determinants and elasticity parameters of both the aggregate import demand and the individual import demand together is more useful than estimating only aggregated import demand elasticity parameters, in policy formulation. Estimating only the aggregated demand function could be misleading if the disaggregated functions behave differently.

\section{A. Objective of the study}

As mentioned above, elasticity of both aggregated and disaggregated import demand would be useful as a tool for policy measures and policy analysis. Studies on price and income elasticity of imports in Sri Lanka focus on aggregate demand [e.g., Sinha (1995 \& 1999), Emran and Shilpi (2001)]. There appears to be a dearth of studies on disaggregated import demand estimates of price and income elasticities of Sri Lanka. The objective of this study is to fill the above gap and identify disaggregated price and income elasticities, specifically for the three major categories of imports, viz. consumer goods, intermediate goods and investment goods.

1/ Disaggregated import demand function means estimating the import demand function for a single product or a product group. 
After economic liberalization in 1977, over the past three to four decades, the composition of exports and imports has been changed, markedly. The composition of exports changed from domination by the agricultural sector to industrial sector while imports change to intermediate goods from consumer goods (See Appendix 1). This study will investigate Sri Lanka's demand for imports only during the post-liberalisation period, i.e., from 1977-2007, based on annual data.

\section{B. Chapter Outline}

The remainder of this paper is organized as follows. Chapter II provides a critical evaluation of existing literature of the field, by discussing findings related to Sri Lanka and other countries. Chapter III describes the model and econometric tools used in the paper, while Chapter IV anylises the results obtained, where by providing necessary interpretations. Finally, Chapter V concludes the discussion on determinants and elasticity of disaggregated import demand of Sri Lanka.

\section{Theoretical Consideration and Review of Literature}

The literature provides a substantial amount of research in this area. Many studies follow the co-integration analysis and estimate an aggregate import demand function (for example see, Carone (1996), Costas (1998), Dilip and Ahmed (1997, 2006), Tang and Nair (2002), among others). However, only a few studies attempts to invesitagate disaggregated import demand functions (Pattichis (1999), Fabiosa and Yekaterina (2000)). Overall, the import demand is modelled as a function of domestic economic activities and relative prices.

In 2002, Tang and Nair presented an empirical analysis of the aggregated import demand behaviour of Malaysia. To estimate the long run relationship between import demand and its determinants, they use an Unrestricted Error Correction Model-Bound Test Analysis. They estimate desired quantity of import demand, assuming that demand for import depends on income and the price, as shown in traditional import demand function. They consider real gross domestic product (GDP) for income and relative price defined as the ratio of the import price index to domestic price level. Their results show that estimated long-run elasticities of import demand with respect to income and relative price are 1.5 and -1.3 , respectively, which lead to the conclusion that monetary, fiscal and exchange rate policies may be used as effective instruments to maintain favorable trade balance.

Dutta and Ahamed (1999) investigate the existence of a long-run aggregate merchandise import demand function for Bangladesh during 1974-1994, by employing cointegration and error correction modeling techniques. They convert all nominal variables 
in to real variables, thus the volume of real imports is determined by real import prices, real GDP and real foreign exchange reserves (export earnings, foreign assistance, and worker remittances). The nominal value of aggregated merchandise imports is deflated by the unite value index of imports in order to obtain real imports. Unit value indices of imports are deflated by domestic prices in order to obtain relative price of imports, foreign exchange reserves are deflated by GDP deflator to obtain real foreign exchange reserves.

They find a unique long-run or equilibrium relationship among real quantities of imports, real import prices, real GDP and real foreign exchange reserves. Thus, their results suggest that import demand is largely explained by real GDP which relates to general level of economic activity.

Sinha (1996) investigates the behaviour of aggregate imports in India and finds no empirical evidence in favour of the existence of any cointegrated relationship among the variables considered in the aggregate import demand function, during 1960-1992. However, Dutta and Ahamed (2006) reinvestigate the behaviour of aggregate imports in India, for the period 1971-1995 and find evidence that aggregate import volume may be cointegrated with relative import price and real GDP. Further, they report that import-demand may be largely explained by real GDP and it is generally less sensitive to changes in the import price. Their findings imply that a decarese of import prices through removal of tariff and non-tariff barriers will not lead to a proportionate rise in the flow of imports. This also reflects the noncompetitive nature of India's imports. Thus, the finding that the quantity of imports is influenced largely by changes in real GDP than import prices is significant, in the sense that it reveals the ineffectiveness of exchange rate policy in influencing import demand. Their model includes a dummy variable to capture the effect of trade liberalisztion policies on import demand, and the estimate is very low implying a little effect of import liberalization policy on aggregate import demand in India during the period considered. However, some studies report contradictory results. For example, Senhadji (1998) assert that the price elasticity is both statistically and economically insignificant for India, reporting an estimate of elasticity as -0.13 with a t-statistic of -0.25 . Similar results are reported by Caporale and Chui (1999) whose estimate of price elasticity is around -0.03 , with a t-statistic of -0.08 .

Milas (1998) examines import demand function in Greece and finds significant evidence in support of a long run relationship with domestic activity (Real GDP) and relative prices, with the latter being weakly exogenous for the long run parameters. While traditional import demand model consists of domestic income and relative price, some researchers attempt to include foreign exchange availability as an explanatory variable.

For example, Emran and Shilpi (1996) find that the estimated price elasticity of aggregate import demand of Bangladesh turns out to be positive, by including foreign 
exchange availability, determined by export earnings, remittances and disbursed foreign aid.

Having described above the international evidence of estimates of import demand faction, the remainder of this section focuses on the literature relating to estimating import demand function in Sri Lanka, among other countries. For example, Sinha (2001) investigates the price and income elasticities of imports and exports in Sri Lanka and other countries, namely India, Japan, the Philippines, and Thailand. They model import demand by including relative price (import price divided by domestic price) and income (which is proxy by real GDP), as explanatory variables. Results of the cointegration tests for the import demand functions are different, in the sense that, for example, there is one cointegrating vector for Japan and Sri Lanka but none exists for India and Thailand. Thus, they use a varity of techniques, such as Phillips-Hansen procedure, for Japan and Sri Lanka, to estimate the import demand function.

Emran and Shilpi (2001) examine foreign trade regime and import demand function. They argue that the changing trade and exchange rate policies have critical bearings on the econometric modeling of aggregate imports, as they determine a country's overall capacity to import. To analyze the aggregate imports of Sri Lanka, they use a structural econometric model of a two-good representative agent economy that incorporates a binding foreign exchange constraint at the administered prices of imports. They compare and contrast the results of the modified traditional model and the foreign exchange availability formulation. According to the modified traditional model the income coefficient has the correct sign, but it is statistically insignificant. The dynamic ordinary least squares (DOLS) estimates have the right signs but both the price and income elasticity estimates are statistically insignificant and implausibly small in magnitude. Their results clearly demonstrate that the traditional model is ill suited for estimating the elasticity parameters in the case of Sri Lanka. According to the foreign exchange availability formulation, the coefficient of foreign exchange availability is highly statistically significant with correct positive sign. Further, the mean of income elasticity estimates with GDP as the scale variable is: 0.96 (based on DOLS) and 1.09 (based on auto-regressive distributed lag -ARDL). The price elasticity estimates are identical at -0.78 , regardless of the estimation technique used (ARDL or DOLS). However, it is found that the estimated price elasticity is much higher, compared to estimates in the literature, for example, Reinhart (1995) reports an estimate of price elasticity -0.30 which is about a two and-a-half times higher, and Sinha (2001) reports an estimate of -0.48 . 


\section{Ill. The Analytical Framework}

This paper examines the import demand function of Sri Lanka by disaggregating the imports in to three main categories, namely, consumer goods, intermediate goods and investment goods. Further, the paper estimates income and price elasticities separately, instead of using an aggregate form, i.e., including all goods in to one model, which may lead to biased results, given the composition of aggregate imports.

\section{A. Methodology and the Model}

This paper employs some standard characterization of models, extensively discussed in the literature. As explained above, it is standard to estimate a model for demand for import with income and relative prices (see for example, Bahmani-Oskooee(1986), Bahmani-Oskooee and Niroomand (1998), Senhadji, (1998), Sinha (1999, 2001), among others). However, some studies include foreign exchange availability as an explanatory variable, albeit, on an ad hoc basis, in order to reflect a binding foreign exchange constraint [see for example, Emran and Shilpi (2001), Mazeri (1995), Moran (1989)] ${ }^{2 /}$. herefore, in this study, we follow standard characterization of the model, which mainly include the variables; real income and relative price. However, we also attempt to incorporate the effects of other variables, such as foreign exchange availability.

As for the price variable, literature provides evidence for both relative and absolute price versions. For example, Sinha (2001) estimates export and import functions by using both relative and absolute price versions. Further, the theory of demand suggests that the quantity variable is more appropriate rather than the value, as dependent variable. Therefore, in this paper, an import volume index is employed as dependent variable. The quantity of imports depends upon the price of imports in domestic currency as well as the price of domestically produced substitutes. Since the data on price of domestically produced substitutes are not available, researchers tend to use a more general price indices, such as the wholesale price index, the consumer price index, the GDP deflator etc. Therefore, the range of goods covered in the domestic price index may differ substantially from those covered in the import unit value index (Dutta and Ahmed 2006).

According to the economic theory, it is expected that an increase in the income of the importing country will raise import demand substantially, if the income elasticity of import demand is high. Other things begin equal, this would lead to a deterioration of the balance of trade. However, this outcome is doubtful in the sense that an increase in income may lead

2/ Also, Some studies construct a log linear formulation in modeling aggregate import demand function [Khan and Ross (1977) and Salas (1982)]. 
to an increase in the production of many goods and services. In that case, one may expect imports to fall in the face of an increase in income (Sinha, 2001), which means that the relationship between volume of imports and income may be either negative or positive.

For import demand functions, the relative price is the ratio of import price to domestic price. An increase in the relative price is expected to lead to a fall in the quantity demanded of import. Therefore, it is expected that the relationship between volume of import demand and relative price to be negative. Further, foreign exchange availability consists of export proceeds, work remittances and disbursed foreign loans and aid. One may expect that a higher foreign exchange availability leads to more imports. Therefore, the relationship between volume of imports and foreign exchange availability may be expected to be positive.

Thus, this paper examines the disaggregated demand for imports in Sri Lanka, categorizing imports into three groups, namely, consumer goods, intermediate goods and investment goods. Following the economic theory and the literature, we employ a standard model for an import demand function, mainly with two variables, i.e., income and relative prices. Further, we also model the effects of foreign exchange availability, as highlighted in the recent literature.

For estimation, we use ordinary least squares (OLS) procedure. Our data sample is from 1977-2007, based on annual data. As time series data often tend to be trended, we carry out some robustness checks of the data in order to avoid spurious results, in that. We test for stationarity of the all data series, using Augmented-Dicky-Fuller (ADF) tests. In cases, where we find evidence of non-stationarity i.e., I(1) data series, we transform the series into first difference in logs. After all, using the first difference of log linear form seems to be more appropriate to estimate elasticity.

\section{The Model}

The import demand function for each category has the following form:

(i) Consumer Goods imports $\quad f$ (Real income, Relative price of Consumer Goods, Foreign Exchange Availability)

(ii) Intermediate Goods imports $f$ (Real income, Relative price of Intermediate Goods, Foreign Exchange Availability)

(iii) Investment Goods imports $f$ (Real income, Relative price of Investment Goods, Foreign Exchange Availability). 
The Models in the log linear form are specified as follows, in that DLn refers to 'first difference in logs':

Model 1: $\mathrm{DL}_{n} \mathrm{CON}_{t} f\left(\beta_{0}+\beta_{1} \mathrm{DL}_{n} \mathrm{GDP}_{t}+\beta_{2} \mathrm{DL}_{n} \mathrm{RPCON}_{t}+\beta_{3} \mathrm{DL}_{n} \mathrm{FEX}_{t}+\mathrm{e}_{t}\right)$

Model 2 : $\mathrm{DL}_{n} \mathrm{INT}_{t} f\left(\alpha_{0}+\alpha_{1} \mathrm{DL}_{n} \mathrm{GDP}_{t}+\alpha_{2} \mathrm{DL}_{n} \mathrm{RPINT}_{t}+\alpha_{3} \mathrm{DL}_{n} \mathrm{FEX}_{t}+\varepsilon_{t}\right)$

Model $3: \mathrm{DL}_{n} \mathrm{INV}_{t} f\left(\delta_{0}+\delta_{1} \mathrm{DL}_{n} \mathrm{GDP}_{t}+\delta_{2} \mathrm{DL}_{n} \mathrm{RPINV}_{t}+\delta_{3} \mathrm{DL}_{n} \mathrm{FEX}_{t}+\mu_{t}\right)$

Where,

$\mathrm{CON}$ is the quantity of consumer goods imports

INT is the quantity of intermediate goods imports

INV is the quantity of investment goods imports

GDP is Gross Domestic Product

RPCON is the relative import price of consumer goods imports, RPCON $=($ IMPCON/DP $)$

RPINT is the relative import price of intermediate goods imports, RPINT= (IMPINT/DP)

RPINV is the relative import price of investment goods imports , RPINV=(IMPINV/DP)

IMPCON is import price of goods consumer goods

IMPINT is import price of goods intermediate goods

IMPINV is import price of goods investment goods

$\mathrm{DP}$ is domestic price

FEX is foreign exchange availability.

In all the models described above, domestic price is proxied by CCPI, income is proxied by GDP at constant prices.

The log linear form of the import demand function means that $\beta_{1}, \alpha_{1}$ and $\delta_{1}$ are income elasticity of import demand, $\beta_{2}, \alpha_{2}$ and $\delta_{2}$ are relative price elasticity of import demand and $\beta_{3}, \alpha_{3}$ and $\delta_{3}$ are foreign exchange availability elasticity of import demand. The data source is various issues of Annual Reports of the Central Bank of Sri Lanka. Please see Appendix II for a detailed description of data. 


\section{Analysis and Findings}

The thrust of this study is to estimate disaggregated price and income elasticities, by examining import demand function for Sri Lanks during post-liberalization period, categorizing aggregate imports as consumer goods, intermediate goods and investment goods. This section presents the empirical findings of the study, first, the unit root test results, followed by estimates of the model.

\section{A. Unite Root Test Results}

Appendix III exhibits the dynamics of the variables considered in this study, for the sample period (1977-2007). It is standard to test for stationarity of the data series to avoid the spurious regression from time series data. If a data series is found to be stationary, it implies that the mean, variance, and autocovarience of the series are independent of time. Several unit root tests exist to examine stationarity of time series data. In this study, we carry out Augmented Dicky-Fuller (ADF) tests, which are used most commonly.

Table 1 - Unit Root Test Results (ADF Method)

\begin{tabular}{|c|c|c|c|c|c|}
\hline \multirow{4}{*}{ Variables } & \multirow{2}{*}{\multicolumn{2}{|c|}{$\frac{\text { Level (in logs) }}{\text { Included }}$}} & \multirow{2}{*}{\multicolumn{2}{|c|}{$\begin{array}{c}\text { First Difference (in logs) } \\
\text { Included }\end{array}$}} & \multirow{3}{*}{ Conclusion } \\
\hline & & & & & \\
\hline & Constant & $\begin{array}{l}\text { Constant \& } \\
\text { Trend }\end{array}$ & Constant & $\begin{array}{c}\text { Constant \& } \\
\text { Trend }\end{array}$ & \\
\hline & Statistics & Statistics & Statistics & Statistics & \\
\hline Import Volume Index-Consumer goods & -1.051474 & -2.852521 & $-5.650326^{*}$ & $-5.697949^{*}$ & $\mathrm{I}(\mathrm{I})$ \\
\hline Import Volume Index-Intermediate goods & -1.209485 & -2.083422 & $-6.487813^{*}$ & $-6.500350^{*}$ & $\mathrm{I}(\mathrm{I})$ \\
\hline Import Volume Index-Investment goods & $-3.001093^{\star *}$ & $-3.68726^{* *}$ & $-4.542654^{*}$ & $-4.389357^{*}$ & $\mathrm{I}(0)$ \\
\hline Import Price Index-Consumer goods & -3.429459 & -3.36575 & $-5.169096^{*}$ & $-5.259567^{*}$ & $\mathrm{I}(\mathrm{I})$ \\
\hline Import Price Index-Intermediate goods & $-4.700943^{*}$ & $-7.788212^{*}$ & $3.592188^{*}$ & $-3.660836^{*}$ & $\mathrm{I}(0)$ \\
\hline Import Price Index-Investment goods & $-3.035321^{* *}$ & -0.831174 & $-4.907688^{*}$ & $-5.457851^{*}$ & $\mathrm{I}(0)$ \\
\hline CCPI Index(1952=100) & -1.491084 & -2.291937 & $-4.079503^{*}$ & $-4.174829^{*}$ & $\mathrm{I}(\mathrm{I})$ \\
\hline Relative price -Consumer goods & $-3.232315^{\star *}$ & $-3.531017^{* * *}$ & $-5.777129^{*}$ & $-5.755194^{*}$ & $\mathrm{I}(0)$ \\
\hline Relative price -Intermediate goods & $-3.403793^{* *}$ & $-7.241608^{*}$ & $-4.302048^{*}$ & $-3.954360^{*}$ & $\mathrm{I}(0)$ \\
\hline Relative price -Investment goods & $-3.183249^{\star *}$ & -2.505259 & $-5.477726^{*}$ & $-5.247784^{*}$ & $\mathrm{I}(0)$ \\
\hline GDP (Constant $-1996=100)$ & -0.304537 & -2.330036 & $-4.316796^{*}$ & $-4.190959^{*}$ & $\mathrm{I}(\mathrm{I})$ \\
\hline Foreign Exchange Availability & -0.930424 & $-3.790496^{* *}$ & $-5.787593^{*}$ & $-5.642049^{*}$ & $\mathrm{I}(\mathrm{I})$ \\
\hline
\end{tabular}

\begin{tabular}{|l|c|c|}
\hline Test critical values: & Constant & Constant \& Trend \\
\hline $1 \%$ level $\left(^{*}\right)$ & -3.67017 & -4.309824 \\
\hline $5 \%$ level $\left(^{* *}\right)$ & -2.963972 & -3.574244 \\
\hline $10 \%$ level $\left.{ }^{* * *}\right)$ & -2.621007 & -3.221728 \\
\hline
\end{tabular}


If the data series is stationary at level, it is called I (0). If the series stationary in first difference or second difference, then they are referred to as integrated of order one, i.e., I (1) and order two i.e., I (2). First, we perform unit root tests at levels, and where necessary we carry out higher order tests. Table 1 confirms the existence of unit roots at levels for most of the variables at 5 per cent significance level. However, ADF tests confirm that all data series are stationary in first differences, at 5 per cent significance level.

\section{B. Estimates of Models \& Findings}

In this section OLS estimates of the three models are presented. The models employed are as follows: Table 2 reports the estimates of the Model I, which describes the demand for consumer goods, Table 3 reports the estimates of Model II, which characterizes the demand for intermediate goods, while Table 4 reports the estimates of Model III, which accounts for the demand for investment goods.

Table 2: OLS estimates of the Model I - Demand for Consumer Goods Imports

Dependent variable: Demand for Consumer Goods Imports

$\mathrm{DL}_{n} \mathrm{CON}_{t}=\beta_{0}+\beta_{1} \mathrm{DL}_{n} \mathrm{GDP}_{t}+\beta_{2} \mathrm{DL}_{n} \mathrm{RPCON}_{t}+\beta_{3} \mathrm{DL}_{n} \mathrm{FEX}_{t}+\beta_{4} \mathrm{DL}_{n} \mathrm{RPCON}_{t-1}+\varepsilon_{t}$

\begin{tabular}{lc}
\hline Independent Variables & Coefficient \\
\hline Constant & 0.019 \\
& $(0.064)$ \\
$\mathrm{DL}_{n} \mathrm{GDP}_{t}$ & $4.96 \mathrm{E}-07$ \\
& $(1.97 \mathrm{E}-06)$ \\
$\mathrm{DL}_{n} \mathrm{RPCON}_{t}$ & $-0.997^{*}$ \\
& $(0.313)$ \\
$\mathrm{DL}_{n} \mathrm{FEX}_{t}$ & -0.198 \\
& $(0.442)$ \\
$\mathrm{RPCON}_{t-1}$ & -0.052 \\
& $(0.241)$ \\
R-squared & 0.353 (adjusted R-squared 0.244$)$ \\
Durbin-Watson stat & 1.957 \\
F-statistic & $3.277^{* *}$ \\
\hline No. of Observations & 29 \\
\hline
\end{tabular}

Notes: Standard errors are parenthesis.

* implies $1 \%$ significance level.

** implies 5\% significance level.

*** implies $10 \%$ significance level. 
Results are rather striking, in that, only relative price of consumer goods is found to have a significant impact on consumer good imports. As Table 2 shows, the sign of the relative price variable is in line with economic theory, which implies a negative sign for the relative price elasticity. The coefficient value of the relative price of consumer good is recorded at -0.997 , revealing that price elasticity of consumer goods is very close to one. Thus, results seem to suggest that when all other variables are held constant (citreous paribas), if import price increases by one percentage point, import volume would decrease nearly by same amount of the price increase. Although the coefficient value is very close to one, one may argue that as it is not equal one (without rounding up the estimate), it may refer to inelasticity. Thus, this estimate yields somewhat inconclusive results, in that, on one hand, it implies that the consumers strongly react to relative price of consumer goods, and on the other, demand for imported consumer goods seem to have some elements of inelasticity.

As for the rest of the variables in the regression, real income (GDP) and foreign exchange availability variables are found to be statistically insignificant at conventional significance levels. This implies that the explanatory power of real income and foreign exchange availability in determining the demand for consumer goods is minimal during the period 1977-2007.

The Durbun-Wotsan statistic is found to be close to two, suggesting that the presence of serial correlation in the residuals of the estimated regression is unlikely. However, the adjusted R-squared value was found to be about 0.24 while the R-squared value was found to be about 0.35 .

F-statistics indicate that all coefficient values are not equal to zero at same time and at least one of them have explanatory power on import demand.

The estimates of Model II (see Table 3), which characterizes the import demand function of intermediate goods, reveals that the coefficient of relative price of intermediate goods is statistically significant at 5 per cent level, marked at -0.46 . This indicates that if relative price of intermediate goods increases by one percentage point, the demand for intermediate goods may fall by 0.46 of a percentage point. Therefore, results suggest that relative price elasticity of intermediate goods is in the range of inelastic, i.e., demand for intermediate goods seems to be less price sensitive.

As for the rest of the variables in the Model II, the coefficient value of foreign exchange availability is marked at 0.497 , which is statistically significant at 10 percent level, and it has the expected sign. This implies that if the foreign exchange availability increases by one percentage point, the demand for intermediate goods will increase by nearly half a percentage point. As coefficient of foreign exchange availability is less than 
Table 3: OLS estimates of the Model II - Demand for Intermediate Goods Imports

Dependent variable: Demand for Intermediate Goods Imports

$$
\begin{aligned}
\mathrm{DL}_{n} \mathrm{INT}_{t}= & \delta_{0}+\delta_{1} \mathrm{DL}_{n} \mathrm{GDP}_{t}+\delta_{2} \mathrm{DL}_{n} \mathrm{RPINT}_{t}+\delta_{3} \mathrm{DL}_{n} \mathrm{FEX}_{t}+\delta_{4} \mathrm{DL}_{n} \mathrm{RPINT}_{t-1} \\
& +\delta_{5} \mathrm{DL}_{n} \mathrm{FEX}_{t-1}+\mu_{t}
\end{aligned}
$$

\begin{tabular}{lc}
\hline Independent Variables & Coefficient \\
\hline Constant & 0.035 \\
& $(0.045)$ \\
$\mathrm{DL}_{n} \mathrm{GDP}_{t}$ & $3.77 \mathrm{E}-07$ \\
& $(1.13 \mathrm{E}-06)$ \\
$\mathrm{DL}_{n} \mathrm{RPINT}_{t}$ & $-0.465^{* *}$ \\
& $(0.176)$ \\
$\mathrm{DL}_{n} \mathrm{FEX}_{t}$ & $0.497^{* * *}$ \\
& $(0.287)$ \\
$\mathrm{DL}_{n} \mathrm{RPINT}_{t-1}$ & 0.228 \\
& $(0.139)$ \\
$\mathrm{DL}_{n} \mathrm{FEX}_{t-1}$ & 0.047 \\
& $(0.271)$ \\
\hline R-squared & 0.297 (adjusted R-squared 0.145$)$ \\
Durbin-Watson stat & 2.104 \\
F-statistic & 3.104 \\
\hline No. of Observations & 29 \\
\hline
\end{tabular}

Notes: Standard errors are parenthesis.

* implies $1 \%$ significance level.

** implies 5\% significance level.

*** implies $10 \%$ significance level.

one (i.e., inelastic), it implies that the demand for intermediate goods is less sensitive to foreign exchange availability.

However, the coefficient of real income seems to be statistically insignificant during the period considered in the present study. The model also includes lagged terms of the relative price and foreign exchange availability, which would help to examine whether there is any lag effect of these variable on demand for imported intermediate goods. However, results imply that coefficients of both lagged terms are statistically insignificant at conventional levels. The Durbun -Wotsan Statistic is found to be close to two, suggesting no serial correlation in the residuals of the estimated regression.

The results of Model III (see Table 4), which characterizes the import demand function of investment goods, show that relative price of investment goods is statistically significant at 5 per cent level. The estimate is -0.753 which implies inelastic relative prices. Therefore, 
Table 4: OLS estimates of the Model III - Demand for Investment Goods Imports

Dependent variable: Demand for Investment Goods Imports

$$
\begin{aligned}
\mathrm{DL}_{n} \mathrm{INV}_{t}= & \delta_{0}+\delta_{1} \mathrm{DL}_{n} \mathrm{GDP}_{t}+\delta_{2} \mathrm{DL}_{n} \mathrm{RPINV}_{t}+\delta_{3} \mathrm{DL}_{n} \mathrm{FEX}_{t}+\delta_{4} \mathrm{DL}_{n} \mathrm{RPINV}_{t-1} \\
& +\delta_{5} \mathrm{DL}_{n} \mathrm{FEX}_{t-1}+\mu_{t}
\end{aligned}
$$

\begin{tabular}{lc}
\hline Independent Variables & Coefficient \\
\hline Constant & -0.013 \\
& $(0.063)$ \\
$\mathrm{DL}_{n} \mathrm{GDP}_{t}$ & $6.80 \mathrm{E}-07$ \\
& $(1.67 \mathrm{E}-06)$ \\
$\mathrm{DL}_{n} \mathrm{RPINV}_{t}$ & $-0.753^{* *}$ \\
& $(0.278)$ \\
$\mathrm{DL}_{n} \mathrm{FEX}_{t}$ & $0.705^{* * *}$ \\
& $(0.408)$ \\
$\mathrm{DL}_{n} \mathrm{RPINV}_{t-1}$ & 0.342 \\
& $(0.231)$ \\
$\mathrm{DL}_{n} \mathrm{FEX}_{t-1}$ & 0.017 \\
& $(0.346)$ \\
\hline R-squared & 0.407 (adjusted R-squared 0.279$)$ \\
Durbin-Watson stat & 2.038 \\
F-statistic & $3.169 * *$ \\
\hline No. of Observations & 29 \\
\hline
\end{tabular}

Notes: Standard errors are parenthesis.

* implies $1 \%$ significance level.

** implies 5\% significance level.

*** implies $10 \%$ significance level.

a one percentage point increase in import prices of investment goods would result in a fall in demand for investment goods by 0.75 of a percentage point. Accordingly, results indicate that the demand for investment goods may be fewer prices sensitive.

On the other variables in the model, the coefficient value of foreign exchange availability is significant at 10 per cent level, reported at 0.70 . It shows that the elasticity of foreign exchange availability is inelastic, in that, a one percentage point increase in foreign exchange availability translates into an increase in the demand for investment good by less than proportionately. The coefficient value is also in the inelastic range.

However, the coefficient of real income variable turns out to be insignificant in the investment demand function in Sri Lanka during 1977-2007. Further, none of the lagged terms of relative price or foreign exchange availability variables are found to be statistically significant at conventional significance levels. 


\section{Summary and Conclusions}

This paper investigates the disaggregate import demand functions in Sri Lanka during 1977-2007, categorizing aggregate imports to three groups, namely, consumer goods, intermediate goods and investment goods. The main aim of the paper is to estimate the disaggregated price and income elasticities of the demand for imported goods, in the post-liberalization period. The demand function is based on traditional import demand function. Nevertheless, following the literature [for example, Emran \& Shilpi $(1996,2001)$ Dutta and Ahamed (1999)], the model is modified to include foreign exchange availability as an explanatory variable in the import demand function.

Results reveal that the coefficient on the relative price under each case, i.e., consumer goods, intermediate goods and investment goods, is statistically significant. The relative price elasticity of the three categories is in the inelastic range, implying that the demand for consumer goods, intermediate goods and investment goods may be of less sensitive to changes in prices. However, comparing results between categories, results suggest that demand for consumer goods are more price sensitive than demand for intermediate and investment goods. The relatively higher elasticity of imported consumer goods compared to intermediate and investment goods reflects the tendency of imported consumer goods to be more non-essential in nature. On the other hand, it may be also due to be the availability of adequate domestic substitutes for the majority of imported consumer goods, particularly food items. Although foreign exchange availability is not statistically significant in the consumer goods demand function, it has a significant impact on the demand for intermediate and investment goods. For both categories, foreign exchange availability turns out to be inelastic, indicating less sensitivity of foreign exchange availability. Despite the perceived importance of real income (GDP) in the demand function, the coefficient value yields statistically insignificant results.

Accordingly, the results of the present study seem to bear out several policy implications, albeit, the results have to be interpreted rather cautiously. First, because of less price elasticity of consumer goods, intermediate goods and investment goods, marked at $-0.99,-0.46$, and -0.75 respectively, if government imposes a tax, it is highly likely that suppliers may pass a great deal of the tax burden on to consumers. However, this implication may be of little relevance for the demand for consumer goods, as the price elasticity is close to one. On the other hand, such a tax may be beneficial on the part of the government, as there would not be much of a decline in demand.

Further, our results are comparable with some of the findings in the literature. For example, Tang and Nair (2002) point out (using data from Malaysia, though) that relative price elasticity and the import volume are sensitive to increase in domestic price level, and 
any increase in domestic inflation rates will trigger a higher volume of imports. Hence, if the increase in the domestic prices is higher than that of import prices, relative price may decrease and this would encourage more imports of the respective goods. Further, it can be illustrated using the coefficient value that if the domestic inflation increases by certain percentage, imports of consumer goods may increase by more than that of investment and intermediate goods. This implies that if imports need to be curtailed, it would demand for lowering domestic inflation, which in turn implies that fiscal and monitory policy may be used as effective policy instruments to maintain domestic inflation at favorable levels to correct trade imbalances.

Second, findings of this study suggest that foreign exchange availability is a significant factor in determining the demand for intermediate and investment goods imports. This implies that, when export earnings, worker remittances and disbursed foreign aids increase, the import demand for intermediate and investment goods would increase, as well. This may have positive effects on the economy due to expansion of production capacity. Therefore, policies with regard to exchange rate stability, foreign employment etc. seem to play a significant role in maintaining the desired level of imports.

Finally, the work may be extended in several dimensions, such as carrying out a cointegration analysis, which will provide adequate inputs for another research paper. 
Annexes

\section{Appedix I - Consumption of Imports 1977-2007}

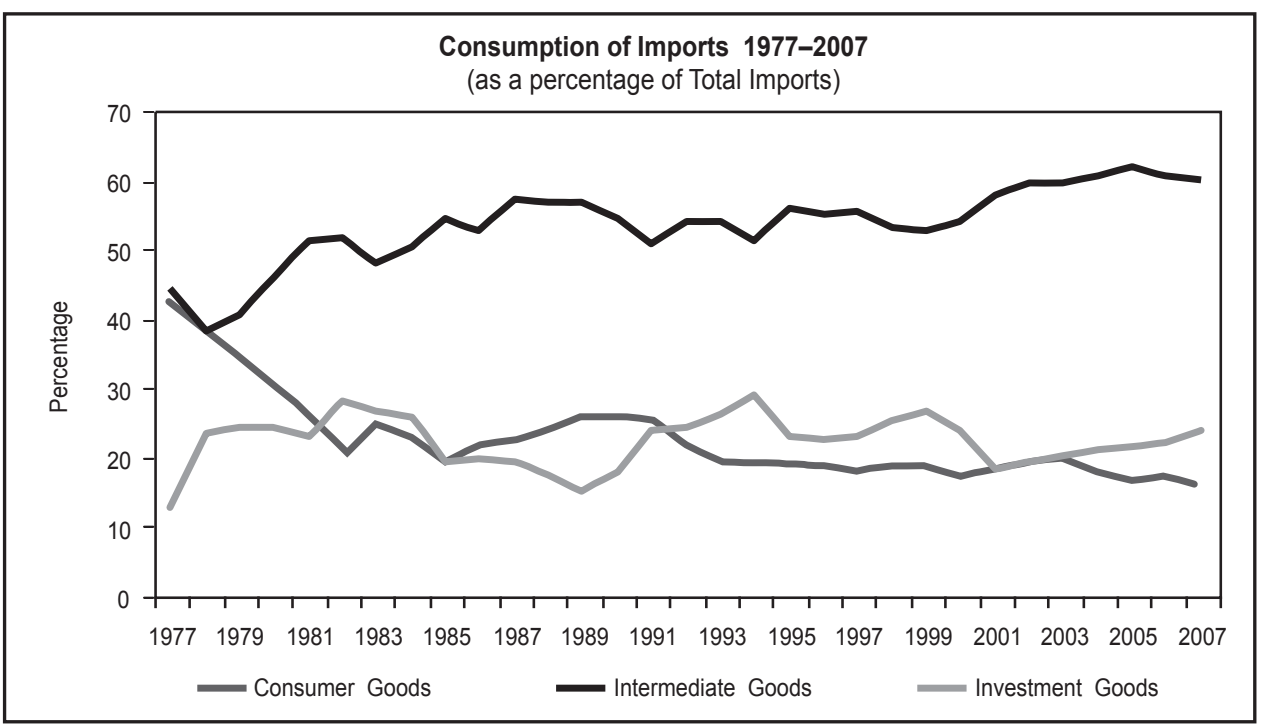

Source : Central Bank of Sri Lanka

\section{Appendix II - Description of Data}

Following annual data used to conduct the analysis:

1. Imports Volume Indices

(Volume index of consumer goods, intermediate goods and investment goods).

2. Import Price Indices in rupee term

(Consumer goods, intermediate goods and investment goods) Employed indices for the sample period are available only rupee term. The indices do not base on one base year. Therefore it was converted one base year (Base year was 1978).

3. Domestic Price (CCPI used as a proxy) $1952=100$.

4. Relative Price (Import Price Index / Domestic Price Index).

5. Gross Domestic Product in rupee term (Constant Price 1996=100).

6. Foreign exchange availability in dollar term

(Export Earnings + Worker Remittances + Disbursed Foreign Aid) 
Appedix III - Dynamics of Variables during 1977-2007
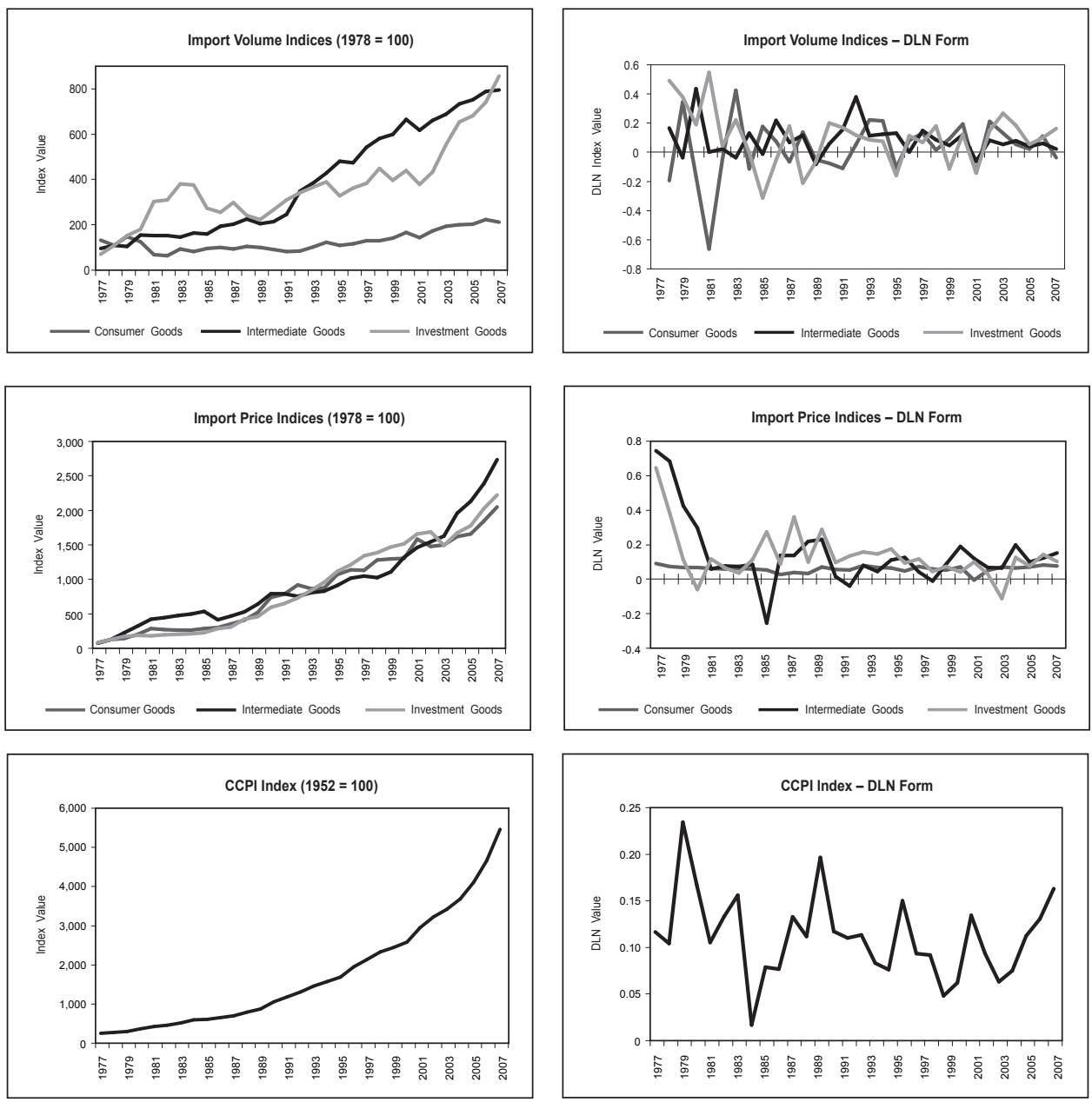

Source : Central Bank of Sri Lanka 

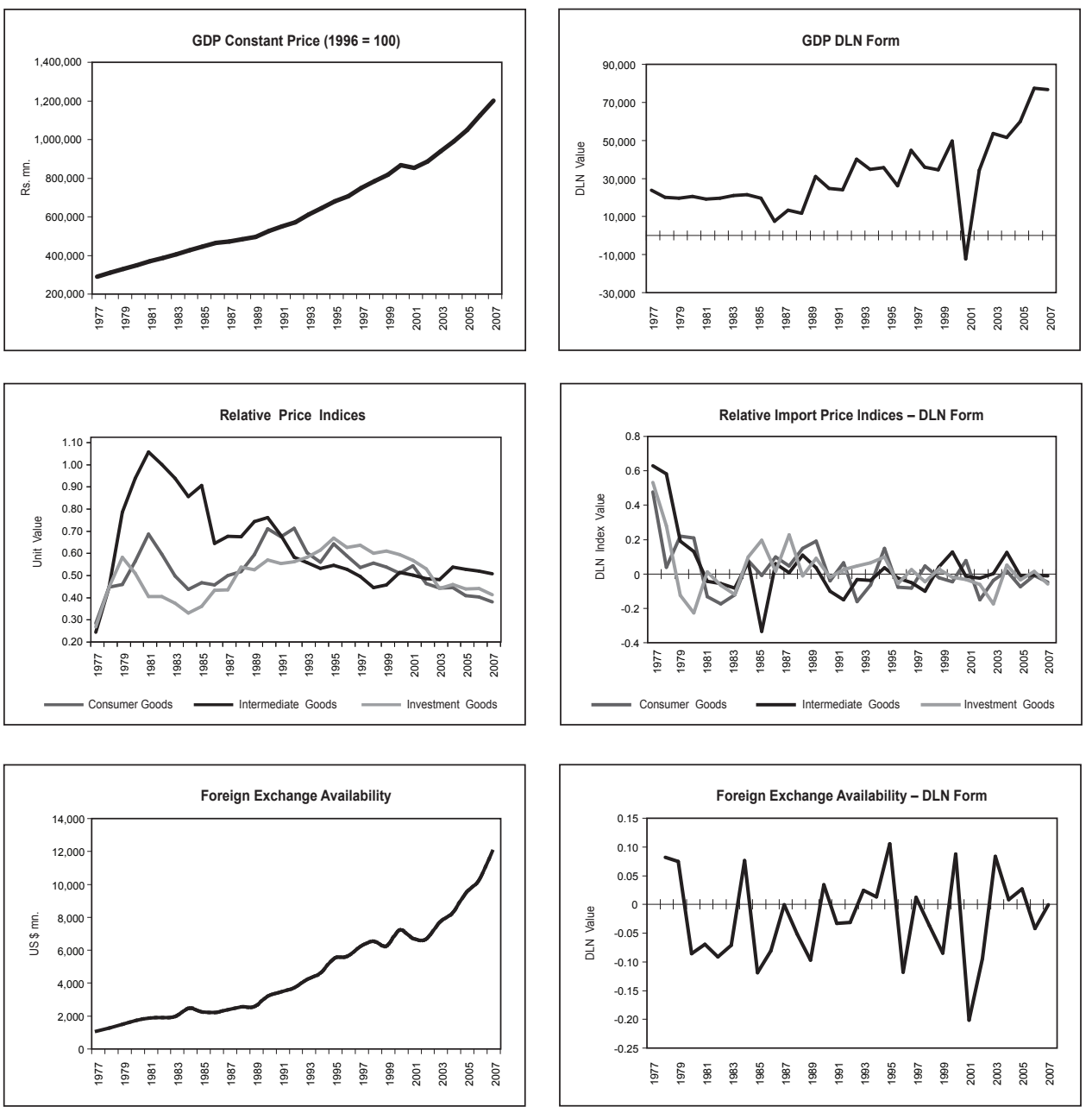

Source : Central Bank of Sri Lanka 


\section{REFERENCES}

1. Bahmani-Oskooee, M. and Niroman, F. (1998), "Loan-run price elasticities and the Marshell- Leaner condition revisited”, Economics Letters, 61:pp.101-109.

2. Costas. M., (1998), "Demand for Greek imports using multivariate cointegration techniques”, Applied Economic, 30: pp.1483-1492.

3. Dutta, D. and Ahmed, N. (1999), “An Aggregate Import Demand Function for Bangladesh: A Cointegration Approach”, Applied Economics, 31: pp.465-472.

4. Dutta, D. and Ahmed, N. (2006), “An Aggregate Import Demand Function for India: A Cointegration Approach”, School of Economics and Political Science, University of Sydney, NSW, Australia.

5. Emran, M. S. and Shilpi, F. (2001), "Foreign Trade regimes and import demand function: Evidence from Sri Lanka”, Stanford University, World Bank, October.

6. Emran, M. S. and F. Shilpi (1996), “Foreign exchange rationing and aggregate import demand function”, Economics Letters, June, pp.315-322.

7. Fabiosa, J. F. and Yekaterina, S. U. (2000), "New aggregated and source-specific pork import demand elasticity for Japan: Implication to US. Exports”, working paper 00-WP 253, October.

8. Goldein, M. and Khan, M . (1985), "Income and price effects in foreign trade”, in hand book of international economics, pp1044-1084.

9. Khan, M., (1974), “Import and export demand in developing countries”, IMF Staff Papers, 21: 678-693.

10. Konno, T. and Fukushige, M. (2002), "The Canada-United States bilateral import demand functions: gradual switching in long - run relationships”, Applied Economics letter,30:pp567-570.

11. Kostan, Z. (1999), “Estimating import demand for Turkey”, Central Bank of the Republic of Turkey, Research Department, Discussion Paper No. 9909.

12. Matsubayabayashi, Y. and Shigeyueki, H. (2003), "Some international evidence on the Stability of aggregate import demand functions", Applied Economics, 35:pp.1497-1504.

13. Pattichis, C. (1999), "Price and income elasticity of disaggregated import demand", Applied Economics, 31:pp.1061-1071.

14. Reinhart, C. (1995), “Devaluation, relative prices, and international trade”, IMF Staff Papers, 42: pp.290-312.

15. Sinha, D.(2001), “A note on trade elasticities in Asian countries”, International Trade Journal, Volume XV, No. 2, Summer, pp.221-237.

16. Tracy, M. and Ginman, P. J. (1976), “An empirical examination of the Traditional Aggregate import demand model", The review of Economic and statistics, Vol. 58, No. 1 pp.79-80. 